\title{
Pengaruh Model Pembelajaran Role Playing Berbasis Tat Twam Asi Terhadap Penguasaan Kompetensi Pengetahuan IPS
}

\author{
I Made Wira Adnyana ${ }^{1 *}$, I Ketut Adnyana Putra ${ }^{2}$, I Nengah Suadnyana ${ }^{3}$
}

123Jurusan Pendidikan Guru Sekolah Dasar, Universitas Pendidikan Ganesha, Indonesia

\section{A R T I CLEINFO \\ Article history: \\ Received 18 Desember 2017 \\ Received in revised form 30 Desember 2017 Accepted 15 Januari 2018 \\ Available online 20 \\ Februari 2018}

\section{Kata Kunci:}

role playing, tat twam asi, penguasaan kompetensi, pengetahuan IPS.

Keywords:

role playing, tat twam asi, competency control, IPS

knowledge

\begin{abstract}
A B S T R A K
Penelitian ini bertujuan untuk mengetahui perbedaan yang signifikan penguasaan kompetensi pengetahuan IPS antara kelompok siswa yang dibelajarkan dengan model pembelajaran role playing berbasis tat twam asi dan kelompok siswa yang dibelajarkan dengan pembelajaran konvensional pada siswa kelas V SD Negeri Gugus Budi Utomo Tahun Ajaran 2016/2017. Penelitian ini merupakan penelitian eksperimen semu dengan rancangan penelitian kelompok nonekuivalen. Sampel penelitian diperoleh dengan cara random sampling yaitu random kelompok dan diperoleh Kelas V SD Negeri 14 Kesiman sebagai kelompok eksperimen dan Kelas V SD Negeri 6 Kesiman sebagai kelompok kontrol. Data yang dikumpulkan adalah data penguasaan kompetensi pengetahuan IPS dan dianalisis menggunakan uji t. Hasil analisis data diperoleh thitung Sebesar 4,634. Dengan menggunakan taraf signifikansi $5 \%$ dan $\mathrm{dk}=67$ diperoleh batas penolakan hipotesis nol sebesar 2,00. Berarti thitung $>$ ttabel yaitu 4,634 $>2,00$, maka Ho yang diajukan ditolak dan menerima Ha. Hasil analisis data kompetensi pengetahuan IPS menunjukkan rata-rata gain skor penguasaan kompetensi pengetahuan IPS siswa kelompok eksperimen $\bar{X}=0,60>\bar{X}=0,41$ rata-rata gain skor kompetensi pengetahuan IPS siswa kelompok kontrol. Jadi dapat disimpulkan bahwa terdapat pengaruh model pembelajaran role playing berbasis tat twam asi terhadap kompetensi pengetahuan IPS siswa kelas V SD Negeri Gugus Budi Utomo Tahun Ajaran 2016/2017.
\end{abstract}

A B S T R A C T

This study aims to determine the significant differences in the mastery of the competence of IPS knowledge between groups of students who are taught by the role-playing model based on tat twam ation and the group of students who were taught by conventional learning in the students of Grade V of the State Elementary School Gugus Budi Utomo of the academic year 2016/2017. This research is a quasi-experimental research with non-equivalent group research design. The sample was obtained by random sampling that is group random and obtained Class V SD Negeri 14 Kesiman as experiment group and Class V SD Negeri 6 Kesiman as control group. The data collected is the data of competency control of IPS knowledge and analyzed using t test. Results of data analysis obtained $t$ count 4.634. Using the $5 \%$ significance level and $\mathrm{dk}=67$ the zero hypothesis rejection limit is reached by 2.00. Means thitung $>$ ttable that is 4.634> 2.00, then the proposed Ho is rejected and accept Ha. Result of data analysis of knowledge competence of IPS showed the average gain gain score of competence knowledge of IPS students experimental group $\bar{X}=0,60>\bar{X}=0,41$ average gain of knowledge competence score of IPS student control group. So it can be concluded that there is influence of role playing model based on tat twam ation to the knowledge competence of IPS student of class V SD Negeri Gugus Budi Utomo academic year 2016/2017

\footnotetext{
${ }^{1}$ Corresponding author.

E-mail addresses: wiradnyanastar@gmail.com
} 



\section{Pendahuluan}

Pendidikan merupakan faktor yang menentukan kualitas suatu bangsa. Pendidikan memiliki peran yang sangat penting, ini dikarenakan pendidikan sebagai sarana meningkatkan kualitas sumber daya manusia. Jika sumber daya manusia pada suatu negara berkualitas, maka dapat dipastikan bahwa negara tersebut makmur dan sejahtera. Kemajuan suatu bangsa, hanya dapat dicapai melalui penataan pendidikan yang baik. Indonesia menempatkan pendidikan sebagai salah satu bidang penting dan utama. Hal ini dapat dilihat dari isi Pembukaan UUD 1945 alinea IV yang menegaskan bahwa salah satu tujuan nasional bangsa Indonesia adalah "mencerdaskan kehidupan bangsa".

Pasal 1 Undang-undang No. 20 tahun 2003 tentang Sistem Pendidikan Nasional menyatakan, Pendidikan adalah usaha sadar dan terencana untuk mewujudkan suasana belajar dan proses pembelajaran agar peserta didik secara aktif mengembangkan potensi dirinya untuk memiliki kekuatan spiritual keagamaan, pengendalian diri, kepribadian, kecerdasan, akhlak mulia, serta keterampilan yang diperlukan dirinya, masyarakat, bangsa dan negara.

Tujuan pendidikan tersebut dapat ditempuh melalui pembelajaran pada jenjang pendidikan formal, salah satunya adalah SD. Proses pembelajaran di SD dilaksanakan berdasarkan pada kurikulum yang berlaku. Dalam sejarah pendidikan, di Indonesia sudah beberapa kali mengalami pergantian kurikulum. Setiap perubahan kurikulum merupakan penyempurnaan dari kurikulum sebelumnya. "Pemerintah melalui Kementerian Pendidikan dan Kebudayaan pada tahun 2013 mengimplementasikan kurikulum baru sebagai penyempurnaan dari kurikulum sebelumnya (KTSP) yang diberi nama kurikulum 2013" (Kunandar,2014:21) . Dalam penerapan kurikulum 2013 pada tingkat SD menggunakan tematik integratif, yaitu mengaitkan beberapa mata pelajaran ke dalam sebuah tema. Sebuah tema terdiri dari beberapa subtema, dalam subtema tersebut terdiri dari 6 pembelajaran. Pada masing-masing pembelajaran terdapat minimal 3 mata pelajaran yang dipadukan, seperti Bahasa Indonesia, Matematika, PKn, IPS, IPA, Penjaskes, dan SBdP. Pemaduan mata pelajaran dalam kegiatan pembelajaran tersebut diusahakan agar siswa tidak menyadari sedang mempelajari mata pelajaran tertentu. Dengan demikian diharapkan siswa dapat memahami suatu konsep dengan utuh bukan hanya sebagai pengetahuan tetapi juga diterapkan melalui kegiatan-kegiatan dalam pembelajaran dan kehidupan sehari-hari. Salah satu mata pelajaran yang ada dalam kegiatan pembelajaran tersebut adalah Ilmu Pengetahuan Sosial (IPS).

Melalui pembelajaran IPS, siswa diarahkan untuk dapat menjadi warga negara Indonesia yang demokratis dan bertanggung jawab, serta warga negara yang cinta damai. Pembelajaran IPS di SD merupakan salah satu program yang dikembangkan secara kurikuler di persekolahan, agar menjadi salah satu alat fungsional guna mencapai tujuan pendidikan nasional, yaitu berdasarkan pasal 3 Undang-undang No. 20 tahun 2003 tentang Sisdiknas menyatakan, Mengembangkan kemampuan dan watak serta peradaban bangsa yang bermartabat dalam rangka mencerdaskan bangsa, bertujuan untuk berkembangnya potensi peserta didik agar menjadi manusia yang beriman dan bertakwa kepada Tuhan Yang Maha Esa, berakhlak mulia, sehat, berilmu, cakap, kreatif, mandiri dan menjadi warga Negara yang demokratis serta bertanggung jawab.

Berdasarkan pernyataan di atas, pendidikan IPS dapat membentuk watak dan kepribadian peserta didik, agar menjadi manusia yang bermartabat, berwawasan tinggi dan menjadi warga negara yang baik yang berguna bagi dirinya, masyarakat, bangsa dan negara. Pembelajaran IPS merupakan salah satu pembelajaran yang membahas tentang keilmuan dasar yang berhubungan dengan kepentingankepentingan sosial, yang lebih menekankan pemahaman dan penghapalan. Dengan demikian proses pembelajaran dari berbagai aspek yang menyertai pembelajaran IPS di SD dituntut untuk dapat memberikan pemahaman yang bermakna bagi siswa.

Namun kenyataannya, masih terdapat proses pembelajaran IPS yang kurang diterima siswa dan memunculkan kebosanan yang berpengaruh terhadap kompetensi pengetahuan IPS siswa. Hal tersebut terlihat pada hasil observasi yang dilakukan di SD Gugus Budi Utomo. Observasi dilakukan pada bulan maret saat pembelajaran IPS kelas V di SD Gugus Budi Utomo. Dari hasil observasi di Gugus Budi Utomo diketahui penguasaan kompetensi pengetahuan siswa masih kurang pada pembelajaran IPS. Hal tersebut terlihat dari hasil wawancara dengan guru kelas V pada masing-masing SD Gugus Budi Utomo, bahwa permasalahan tersebut disebabkan karena proses pembelajaran cenderung mengejar target ketercapaian materi yang diberikan, siswa yang kurang termotivasi untuk aktif dalam pembelajaran, dan siswa belum diberikan kesempatan untuk menemukan sendiri konsep yang dipelajari. Sehingga proses pembelajaran IPS yang berlangsung, tampak belum menggunakan model pembelajaran yang inovatif dan mengakibatkan penguasaan kompetensi pengetahuan siswa kelas V SD Gugus Budi Utomo kurang optimal.

Untuk mengatasi permasalahan tersebut maka dilakukan suatu penelitian. Salah satu cara yang dapat dilakukan adalah dengan menerapkan model pembelajaran yang inovatif agar situasi pembelajaran menjadi menyenangkan, aktif, dan bermakna bagi siswa. Salah satu model pembelajaran yang mendukung 
adalah model pembelajaran role playing berbasis tat twam asi. Melalui model pembelajaran role playing menekankan kepada siswa dengan memberikan pengalaman langsung dalam memahami materi pelajaran dan memberikan kesempatan kepada siswa untuk aktif membangun pengetahuannya sendiri. Karena dalam model pembelajaran role playing siswa akan mempratekan materi dalam bentuk bermain drama. Hal tersebut akan membuat pengetahuan siswa tidak berupa hapalan semata, tetapi berupa pemahaman. Sehingga tidak cepat dilupakan siswa dan memberi dampak positif terhadap kompetensi pengetahuan siswa.

Proses pembelajaran yang dilaksanakan akan lebih bermakna, apabila didukung dengan ajaran tat twam asi. Melalui ajaran tat twam asi akan menumbuhkan sikap saling menghargai, saling menghormati dan saling membantu terhadap siswa. Karena manusia diciptakan sebagai makhluk sosial dan makhluk individu. Sebagai makhluk sosial manusia memerlukan bantuan orang lain atau sesamanya. Disarmping itu, manusia adalah makhluk individu yang dimana tidak terbagi atau satu kesatuan dan mempunyai karakteristik yang berbeda satu dengan yang lainnya. Dengan demikian, pembelajaran IPS sangat penting ditanamkan sejak dini agar siswa dapat berinteraksi dengan baik.

Berdasarkan temuan-temuan tersebut, maka diadakan penelitian dengan judul "Pengaruh Model Pembelajaran Role Playing Berbasis Tat Twam Asi Terhadap Penguasaan Kompetensi Pengetahuan IPS Siswa Kelas V SD Gugus Budi Utomo Tahun Ajaran 2016/2017."

\section{Metode}

Penelitian ini bertempat di kelas V SD Negeri Gugus Budi Utomo Kecamatan Denpasar Timur. Penelitian ini dilaksanakan pada semester genap tahun pelajaran 2016/2017. Penelitian yang dilaksanakan menggunakan metode eksperimen dengan rancangan penelitian yaitu rancangan eksperimen semu. Bentuk rancangan eksperimen semu yang digunakan dalam penelitian yaitu rancangan kelompok Non-ekuivalen. Penelitian bentuk ini biasanya dipakai pada eksperimen yang menggunakan kelas yang sudah terbentuk dan tidak dilakukannya pengacakan individu dalam menentukan sampel yang dijadikan sebagai kelompok eksperimen dan kelompok kontrol. Pada awalnya, pre test diberikan kepada sampel penelitian untuk penyetaraan. Setelah disetarakan, kelompok eksperimen diberikan perlakuan yaitu dibelajarkan dengan model pembelajaran role playing berbasis tat twam asi. Sedangkan kelompok kontrol dibelajarkan dengan pembelajaran konvensional. Kemudian, pada akhir penelitian kedua kelompok diberikan posttest.

Pelaksanaan penelitian ini terdiri dari tiga tahapan yaitu tahap persiapan eksperimen, tahap pelaksanaan eksperimen, dan tahap akhir eksperimen. Pada tahap persiapan eksperimen, kegiatan yang dilakukan yaitu (a) melakukan wawancara dengan masing-masing kepala SD dan wali kelas V SD Negeri Gugus Budi Utomo Kecamatan Denpasar Timur untuk mengetahui informasi dasar dan ada atau tidaknya kelas unggulan di SD Negeri Gugus Budi Utomo Kecamatan Denpasar Timur tersebut, (b) mempersiapkan media dan sumber belajar yang digunakan untuk membelajarkan kelas eksperimen, (c) menyusun RPP, (d) menyusun instrumen penelitian untuk mengukur kompetensi pengetahuan IPS siswa, (e) mengadakan validasi instrumen penelitian, (f) menentukan sampel penelitian, (g) melakukan penyetaraan sampel dengan memberikan pretest, (h) menganalisis data pretest, serta (i) menentukan kelompok eksperimen dan kelompok kontrol.

Pada saat pelaksanaan eksperimen kegiatan yang dilakukan yaitu (a) memberikan perlakuan kepada kelompok eksperimen berupa penerapan model pembelajaran role palying berbasis tat twam asi sejumlah 6 kali pembelajaran, dan (b) menerapkan pembelajaran konvensional pada kelompok kontrol sejumlah 6 kali pembelajaran. Pada tahap akhir eksperimen, kegiatan yang dilakukan yaitu (a) memberikan posttest pada akhir penelitian untuk kelompok eksperimen dan kelompok, (b) menganalisis data hasil penelitian, serta (c) menguji hipotesis.

Populasi adalah keseluruhan objek dalam suatu penelitian yang mempunyai kualitas dan karakteristik tertentu yang ingin diteliti untuk dipelajari dan didapat sebuah kesimpulan. Populasi pada penelitian ini adalah seluruh siswa kelas V SD Negeri di Gugus Budi Utomo Kecamatan Denpasar Timur Tahun Pelajaran 2016/2017, yang terdiri dari 9 kelas V dalam 7 SD. Terdapat 7 SD Negeri di Gugus I Gusti Ngurah Rai Kecamatan Denpasar Timur, yaitu SD Negeri 1 Kesiman, SD Negeri 2 Kesiman, SD Negeri 5 Kesiman, SD Negeri 6 Kesiman, SD Negeri 8 Kesiman, SD Negeri 11 Kesiman, dan SD Negeri 14 Kesiman. Jumlah populasi dari penelitian ini adalah 314 siswa. Berdasarkan hasil wawancara pada bulan februari 2017 dengan kepala sekolah serta guru kelas V di masing-masing SD Negeri Gugus Budi Utomo Kecamatan Denpasar Timur, diperoleh informasi bahwa 9 kelas V dari 7 SD tersebut tidak terdapat kelas unggulan, serta dinyatakan setara secara akademik yang memiliki nilai rata-rata yang tidak jauh berbeda.

Sampel adalah bagian dari jumlah dan karakteristik yang dimiliki populasi dan dianggap mewakili, serta diambil dengan teknik tertentu. Teknik pengambilan sampel pada penelitian tersebut adalah random 
sampling. Random pada penelitian tersebut dilakukan terhadap kelompok yaitu kelas bukan random individu. Teknik tersebut digunakan agar setiap kelas mendapatkan peluang yang sama untuk menjadi sampel penelitian. Pengambilan sampel secara random dapat dilakukan dengan undian (Sugiyono, 2016). Sampel yang diperoleh dari hasil random tersebut selanjutnya diberikan pretest untuk penyetaraan. Nilai dari hasil pretest dianalisis menggunakan uji t. Sebelum uji kesetaraan menggunakan uji t, data hasil pretest diuji prasyarat yaitu normalitas dan homogenitas.

Uji prasyarat analisis yang dilakukan pertama sebelum uji t yaitu uji normalitas nilai pretest sampel penelitian dengan menggunakan rumus Chi Kuadrat pada taraf signifikansi 5\% dengan dk n-1. Kriteria pengujian adalah jika ${ }^{\chi 2}$ hitung $\leq^{\chi 2}$ tabel maka data berdistribusi normal. Setelah diuji normalitas, diperoleh bahwa sebaran data sampel penelitian berdistribusi normal. Kemudian dilanjutkan dengan pengujian homogenitas menggunakan uji F pada taraf signifikansi 5\% dengan dk pembilang n-1 dan dk penyebut n1. Kriteria pengujian adalah jika $\mathrm{F}$ hitung $\leq \mathrm{F}$ tabel maka data homogen. Hasil pengujian menunjukkan bahwa data nilai pretest homogen.

Setelah data nilai pretest kedua kelompok dinyatakan berdistribusi normal dan homogen, dilanjutkan dengan penyetaraan sampel menggunakan uji t. Kesetaraan sampel diuji dengan rumus uji $t$ yakni bentuk polled varian karena jumlah $\mathrm{n}_{1} \neq \mathrm{n}_{2}$. Hasil $\mathrm{t}$ hitung tersebut kemudian dibandingkan dengan $\mathrm{t}$ tabel pada taraf signifikansi $5 \%$ dan $\mathrm{dk}=\mathrm{n}_{1}+\mathrm{n}_{2}-2$. Jika nilai $\mathrm{t}$ hitung $\leq \mathrm{t}$ tabel, maka kedua kelompok dinyatakan setara. Berdasarkan hasil pengujian, diperoleh $t$ hitung $(0,835)<t$ tabel $(2,000)$ dan kedua kelompok dinyatakan setara. Setelah sampel dinyatakan setara, maka dilanjutkan dengan melakukan pengundian kedua untuk menentukan kelas eksperimen dan kelas kontrol. Dari hasil pengundian diperoleh kelas V SD Negeri 14 Kesiman sebagai kelompok eksperimen dan kelas V SD Negeri 6 Kesiman sebagai kelompok kontrol.

Variabel penelitian adalah sesuatu yang ditetapkan peneliti dan dijadikan titik fokus penelitian untuk dipelajari dan didapat kesimpulannya. Variabel dalam penelitian ini terdiri dari dua variabel yaitu variabel bebas dan variabel terikat. Variabel bebas merupakan variabel yang memengaruhi dan menjadi sebab perubahan pada variabel dependen atau terikat (Sugiyono, 2016). Variabel bebas dalam penelitian ini adalah model pembelajaran role playing berbasis tat twam asi yang diterapkan pada kelompok eksperimen. "Variabel terikat merupakan variabel yang dipengaruhi atau yang menjadi akibat, karena adanya variabel bebas" (Sugiyono, 2016:39). Variabel terikat dalam penelitian ini adalah penguasaan kompetensi pengetahuan IPS.

Pengumpulan data dalam penelitian ini meliputi data penguasaan kompetensi pengetahuan IPS. Data yang diperlukan dalam penelitian ini dikumpulkan dengan metode tes. Metode tes merupakan cara dalam memperoleh data dengan memberikan suatu tugas yang harus dikerjakan oleh seorang atau kelompok orang yang dites dan menghasilkan data berupa skor (Agung, 2014:92). Jenis instrumen yang digunakan pada penelitian ini berupa tes objektif. Tes objektif yang digunakan dalam penelitian ini adalah bentuk pilihan ganda biasa dengan 4 pilihan jawaban $(a, b, c, d)$ sejumlah 40 butir yang diuji coba terlebih dahulu pada kelas yang lebih tinggi dari kelas yang diteliti yaitu diuji coba pada kelas VI. Data yang dihasilkan melalui tes tersebut adalah berupa angka. Dilihat dari data yang dihasilkan, maka data tersebut tergolong data kuantitatif. Pemeriksaan hasil tes siswa dilakukan berdasarkan kunci jawaban yang benar. Skor 0 diberikan untuk siswa yang menjawab salah dan skor 1 untuk siswa yang menjawab benar pada setiap butir tes. Jadi skor setiap jawaban dijumlahkan dan jumlah tersebut menjadi skor variabel penguasaan kompetensi pengetahuan IPS. Penilaian pada hasil tes menggunakan skala 100. 0 merupakan nilai minimal dan 100 merupakan nilai maksimal tes penguasaan kompetensi pengetahuan IPS. Tes yang digunakan dalam penelitian ini bersifat terstandar, yaitu tes yang memenuhi kriteria-kriteria tertentu. Karena termasuk tes standar, maka instrumen tersebut terlebih dahulu diuji validitas, daya beda, tingkat kesukaran, dan reliabilitasnya.

Sebuah tes disebut valid apabila tes tersebut dapat dengan tepat mengukur apa yang hendak diukur. Uji validitas yang digunakan dalam penelitian ini terdiri dari dua jenis yaitu validitas isi dan validitas butir. Validitas isi dilakukan dengan cara menyesuaikan item tes dengan materi kurikulum atau materi pembelajaran. Instrumen disusun berdasarkan kisi - kisi yang telah dibuat. Kisi-kisi dan instrumen yang telah disusun tersebut kemudian ditelaah oleh expert judges atau pakar yang ahli. Pengukuran validitas butir tes penguasaan kompetensi pengetahuan IPS dalam bentuk tes objektif dihitung dengan rumus koefisien korelasi biserial $\left(\mathrm{r}_{\mathrm{pbi}}\right)$. Berdasarkan hasil pengujian dari 40 soal diperoleh 20 soal memiliki $r_{\text {hitung }}$ lebih dari $r_{\text {tabel }}(0,355)$, sehingga 20 soal dinyatakan valid. Sedangkan 20 soal dinyatakan tidak valid karena memiliki $r_{\text {hitung }}$ kurang dari $r_{\text {tabel }}(0,355)$. Soal yang tidak valid tersebut kemudian di drop (tidak digunakan).

Daya beda adalah kemampuan suatu butir tes untuk membedakan antara siswa yang berkemampuan tinggi dan siswa yang berkemampuan rendah (Suharsimi, 2015). Berdasarkan kriteria 
yang telah ditentukan, maka hasil pengujian daya beda diperoleh 5 soal dengan kriteria baik sekali, 10 soal dengan kriteria baik, 5 soal dengan kriteria cukup.

Soal yang baik adalah soal yang tidak terlalu mudah atau tidak terlalu sukar. "Soal yang terlalu mudah tidak merangsang siswa untuk mempertinggi usaha memecahkannya, sebaliknya soal yang terlalu sukar akan menyebabkan siswa menjadi putus asa dan tidak mempunyai semangat untuk mencoba lagi karena di luar jangkauannya" (Suharsimi , 2015:222). Berdasarkan hasil pengujian tingkat kesukaran, diperoleh 4 soal dengan kategori mudah, 12 soal dengan kategori sedang, dan 4 soal dengan kategori sukar.

"Suatu tes dapat dikatakan mempunyai taraf kepercayaan yang tinggi jika tes tersebut dapat memberikan hasil yang tetap" (Suharsimi, 2015:100). Reliabilitas berhubungan dengan ketetapan suatu tes. Uji reliabilitas hanya dilakukan terhadap butir tes yang valid. Jadi, uji reliabilitas dapat dilakukan setelah melakukan uji validitas. Uji reliabilitas tes yang bersifat dikotomi (objektif) dan heterogen ditentukan dengan rumus Kuder Richardson (KR-20). Berdasarkan hasil pengujian terhadap 20 soal yang telah memenuhi kriteria diperoleh $r_{11}=0,87$, karena $r_{11}>0,70$ maka butir tes yang dijadikan instrumen dalam penelitian tergolong reliabel.

Data penguasaan kompetensi pengetahuan IPS dikumpulkan dengan instrumen berupa tes pilihan ganda biasa berjumlah 20 butir tes yang telah diuji validitas, daya beda, tingkat kesukaran, dan reliabilitas. Data dalam penelitian ini dianalisis menggunakan statistik deskriptif dan statistik inferensial. Analisis data dengan statistik deskriptif tersebut dilakukan dengan cara mendeskripsikan data yang telah terkumpul tanpa bermaksud membuat kesimpulan untuk digeneralisasikan pada populasi (Sugiyono, 2016). Statistik inferensial adalah statistik yang digunakan untuk menganalisis data sampel, menguji hipotesis, dan hasilnya dapat digeneralisasikan untuk populasi (Sugiyono, 2016). Sebelum dilakukan uji hipotesis, terlebih dahulu dilakukan uji prasyarat analisis. Uji prasyarat analisis dilakukan terhadap gain skor ternormalisasi data penguasaan kompetensi pengetahuan IPS. Hal tersebut dilakukan agar hasil penguasaan kompetensi pengetahuan IPS siswa memang mencerminkan perlakuan, dan bukan karena pengaruh dari pemberian pretest.

Uji normalitas data dimaksudkan untuk mengetahui sebaran gain skor data penguasaan kompetensi pengetahuan IPS siswa kelompok eksperimen dan kelompok kontrol berdistribusi normal atau tidak, agar dapat menentukan teknik analisis data yang digunakan. Uji normalitas sebaran data dalam penelitian ini menggunakan rumus Chi Kuadrat. Hasil Chi Kuadrat hitung kemudian dibandingkan dengan Chi Kuadrat tabel pada taraf signifikansi $5 \%$ dan derajat kebebasan $n-1$. Kriteria pengujian adalah jika $x^{2}$ hitung $\leq$ $x^{2}$ tabel, maka data dinyatakan berdistribusi normal. Sedangkan jika $x^{2}$ hitung $>x^{2}$ tabel, maka data dinyatakan tidak berdistribusi normal.

Uji homogenitas varian dilakukan untuk memastikan bahwa sebaran data dari kedua kelompok yang akan dibandingkan homogen. Uji homogenitas varian dilakukan setelah kedua kelompok data tersebut dinyatakan berdistribusi normal. Uji homogenitas varian dilakukan dengan uji F. Hasil dari $F_{\text {hitung }}$ kemudian dibandingkan dengan $F_{\text {tabel }}$ pada taraf signifikansi 5\% dengan derajat kebebasan untuk pembilang n-1 dan derajat kebebasan untuk penyebut n-1. Kriteria pengujian, jika $F_{\text {hitung }} \leq F_{\text {tabel }}$ maka varian data kedua kelompok dinyatakan homogen. Sedangkan jika $F_{\text {hitung }}>F_{\text {tabel }}$ maka varian data kedua kelompok dinyatakan tidak homogen.

Data yang telah memenuhi syarat uji normalitas dan homogenitas varian, dilanjutkan dengan uji hipotesis. Jika data yang diperoleh sudah memenuhi prasyarat uji normalitas dan homogenitas maka analisis yang digunakan adalah statistik parametris. Pada statistik parametris, uji hipotesis menggunakan uji t test dengan bentuk rumus polled varian. Rumus uji t dengan rumus polled varian digunakan karena jumlah anggota sampel tidak sama yaitu $\mathrm{n}_{1} \neq \mathrm{n}_{2}$ dengan varian homogen. Hasil $\mathrm{t}$ hitung kemudian dibandingkan dengan $t$ tabel pada taraf signifikansi $5 \%$ dengan $d k=n_{1}+n_{2}-2$. Dengan kriteria jika $t$ hitung $\leq \mathrm{t}$ tabel, maka $\mathrm{H}_{\mathrm{o}}$ diterima, dan jika $\mathrm{t}$ hitung $>\mathrm{t}$ tabel maka $\mathrm{H}_{\mathrm{o}}$ ditolak.

\section{Hasil dan Pembahasan}

Hasil analisis statistik deskriptif penguasaan kompetensi pengetahuan IPS siswa baik kelas eksperimen maupun kelas kontrol dapat dilihat pada tabel 1 berikut.

Tabel 1. Hasil Analisis Statistik Deskriptif Penguasaan Kompetensi Pengetahuan IPS Kelas Eksperimen dan Kelas Kontrol

\begin{tabular}{ccc}
\hline Statistik Deskriptif & Kelas Eksperimen & Kelas Kontrol \\
\hline Gain Skor Minimum & 0,11 & 0,09 \\
\hline
\end{tabular}




\begin{tabular}{ccc}
\hline Gain Skor Maksimum & 1,00 & 0,75 \\
\hline Statistik Deskriptif & Kelas Eksperimen & Kelas Kontrol \\
\hline Rata-rata Gain Skor & 0,60 & 0,41 \\
\hline Standar Deviasi & 0,19 & 0,15 \\
\hline Varian & 0,037 & 0,023 \\
\hline
\end{tabular}

Berdasarkan dengan hasil analisis data kompetensi pengetahuan IPS menunjukkan bahwa rata-rata gain skor kompetensi pengetahuan IPS siswa kelompok eksperimen $(\overline{\mathrm{X}}=0,60)$ lebih besar dari rata-rata gain skor kompetensi pengetahuan IPS siswa kelompok kontrol $(\bar{X}=0,41)$.

Hasil uji normalitas data kelompok eksperimen eksperimen diperoleh ${ }^{x} 2$ hitung $<{ }^{x} 2$ tabel $(7,98<$ 11,070), maka gain skor data penguasaan kompetensi pengetahuan IPS kelompok eksperimen dinyatakan berdistribusi normal. Hasil uji normalitas data kelompok kontrol diperoleh ${ }^{{ }} 2$ hitung $<{ }^{{ } 2 \text { tabel }(8,48<}$ 11,070), maka gain skor data penguasaan kompetensi pengetahuan IPS kelompok kontrol dinyatakan berdistribusi normal. Hasil uji homogenitas varian data penguasaan kompetensi pengetahuan IPS kelompok eksperimen dan kelompok kontrol diperoleh $\mathrm{F}$ hitung $<\mathrm{F}$ tabel $(1,16<1,68)$, maka varian sebaran gain skor data kelompok eksperimen dan kelompok kontrol dinyatakan homogen.

Setelah memenuhi uji prasyarat, selanjutnya dilakukan uji hipotesis dengan rumus uji-t bentuk polled varian dengan kriteria jika kriteria jika $\mathrm{t}$ hitung $\leq \mathrm{t}$ tabel, maka Ho diterima, dan jika $\mathrm{t}$ hitung $>\mathrm{t}$ tabel maka Ho ditolak. Pada taraf signifikansi $5 \%$ dengan $d k=n 1+n 2-2$. Hipotesis yang diuji dalam penelitian ini adalah tidak terdapat perbedaan yang signifikan penguasaan kompetensi pengetahuan IPS antara kelompok siswa yang dibelajarkan dengan model pembelajaran role playing berbasis tat twam asi dan kelompok siswa yang dibelajarkan dengan pembelajaran konvensional pada kelas V SD Negeri Gugus Budi Utomo Kecamatan Tahun Ajaran 2016/2017. Rekapitulasi hasil uji hipotesis data penguasaan kompetensi pengetahuan IPS dapat dilihat pada tabel 2.

Tabel 2. Rekapitulasi Hasil Uji Hipotesis Data Penguasaan Kompetensi Pengetahuan IPS

\begin{tabular}{cccccccc}
\hline $\begin{array}{c}\text { Sampel } \\
\text { Penelitian }\end{array}$ & $\mathrm{N}$ & $\mathrm{Dk}$ & $\overline{\boldsymbol{X}}$ & $\mathrm{s}^{2}$ & thitung & t tabel & Keterangan \\
\hline $\begin{array}{c}\text { Kelas } \\
\text { Ekesperimen }\end{array}$ & 36 & 67 & 0,60 & 0,037 & 4,634 & 2,000 & $\mathrm{H}_{\mathrm{o}}$ ditolak \\
Kelas Kontrol & 33 & & 0,41 & 0,023 & & & \\
\hline
\end{tabular}

Berdasarkan tabel tersebut diketahui bahwa data penguasaan kompetensi pengetahuan IPS kelompok eksperimen dan kelompok kontrol memperoleh $t$ hitung $=4,634$. Nilai $t$ hitung tersebut dibandingkan dengan $\mathrm{t}$ tabel $=2,000$. Karena $\mathrm{t}$ hitung $>\mathrm{t}$ tabel, maka Ho ditolak. Hal tersebut menunjukkan bahwa terdapat perbedaan yang signifikan penguasaan kompetensi pengetahuan IPS antara kelompok siswa yang dibelajarkan dengan model pembelajaran role playing berbasis tat twam asi dan kelompok siswa yang dibelajarkan dengan pembelajaran konvensional pada kelas V SD Negeri Gugus Budi Utomo Tahun Ajaran 2016/2017.

Penelitian yang dilaksanakan terbatas pada materi kelas V tema 8 Ekosistem pada pembelajaran yang terdapat muatan materi IPS sesuai Kurikulum 2013. Pada akhir penelitian di kelas eksperimen dan kelas kontrol diberikan posttest untuk mendapatkan data penguasaan kompetensi pengetahuan IPS siswa. Hasil analisis data dari kedua kelompok yaitu kelompok eksperimen memperoleh nilai rata- gain skor kelompok eksperimen memperoleh 0,60>0,41 rata-rata gain skor yang diperoleh kelompok kontrol. Sehingga dapat disimpulkan bahwa kelompok eksperimen yang dibelajarkan dengan model pembelajaran role playing berbasis tat twam asi memperoleh penguasaan kompetensi pengetahuan yang lebih tinggi dibandingkan kelompok kontrol yang dibelajarkan dengan pembelajaran konvensional.

Perolehan hasil uji hipotesis dari data penguasaan kompetensi pengetahuan IPS yang dianalisis melalui gain skor ternormalisasi kedua kelompok adalah $t$ hitung $(4,634)>t$ tabel $(2,000)$. Berdasarkan hasil hitung tersebut dapat disimpulkan bahwa hipotesis yang berbunyi terdapat perbedaan yang signifikan penguasaan kompetensi pengetahuan IPS antara kelompok siswa yang dibelajarkan dengan model pembelajaran role playing berbasis tat twam asi dan kelompok siswa yang dibelajarkan dengan pembelajaran konvensional pada kelas V SD Negeri Gugus Budi Utomo Tahun Ajaran 2016/2017 diterima. Karena terdapat perbedaan yang signifikan, maka terdapat pengaruh model pembelajaran role playing berbasis tat twam asi terhadap penguasaan kompetensi pengetahuan IPS siswa kelas V SD Negeri Gugus Budi Utomo Tahun Ajaran 2016/2017. Jadi, model pembelajaran role playing berbasis tat twam asi dapat 
direkomendasikan dalam membelajarkan siswa khususnya pada kegiatan pembelajaran yang terdapat muatan materi IPS.

Berdasarkan perolehan penguasaan kompetensi pengetahuan IPS pada kedua kelompok dapat diketahui bahwa kedua kelompok yang pada mulanya memiliki kemampuan setara, setelah diberikan perlakuan yang berbeda perolehan penguasaan kompetensi pengetahuan IPS mengalami perbedaan. Perbedaan tersebut disebabkan karena pembelajaran yang diterapkan pada kelompok eksperimen memiliki kelebihan dibandingkan pembelajaran yang diterapkan pada kelompok kontrol. Pembelajaran yang menerapkan model pembelajaran role playing berbasis tat twam asi mampu membangkitkan rasa antusiasme siswa dalam mengikuti pembelajaran dan meningkatkan keaktifan siswa dalam proses pembelajaran. memerankan sebuah tokoh.

Pembelajaran menggunakan model pembelajaran role playing berbasis tat twam asi pada muatan materi IPS memberikan kesempatan yang lebih luas kepada siswa untuk mengonstruksikan pengetahuannya melalui berbagai kegiatan bermakna dan teratur yang tentunya menggembirakan bagi siswa pada setiap langkah pembelajarannya. Hasil penelitian ini diperkuat penelitian yang dilakukan oleh Ardian Biantara dengan judul penelitian pengaruh penggunaan metode role playing terhadap hasil belajar IPS pada siswa kelas V SD Negeri Blondo 3 Kecamatan Mungkid Kabupaten Magelang, dilihat dari nilai rata - rata kompetensi pengetahuan IPS kelas eksperimen terjadi peningkatan yaitu 19,1, sedangkan pada hasil belajar kelas kontrol peningkatan rata-rata nilai hanya 9,35. Pada peningkatan nilai rata-rata menyatakan bahwa nilai $t$ hitung sebesar 2,738. Nilai $t$ hitung $>t$ tabel $(2,738>1,686)$. Hal ini menunjukkan ada pengaruh secara signifikan dari perbedaan perlakuan yang diterima pada kedua kelas.

Kajian penelitian tersebut adalah sama-sama melakukan penelitian eksperimen dan meneliti tentang model pembelajaran role playing dan hasil belajar berupa pengetahuan IPS. Perbedaannya adalah penelitian tersebut tidak mengunakan tat twam asi sebagai landasannya, sedangkan pada penelitian ini menggunakan tat twam asi sebagai landasannya. Dari uraian tersebut dapat disimpulkan bahwa model pembelajaran role playing berpengaruh terhadap hasil belajar IPS, hal tersebut dikarenakan model pembelajara role playing dapat membuat siswa lebih aktif dan suasana kelas akan menjad menyenangkan, sehingga nanti model pembelajaran role playing juga akan berpengaruh pada kompetensi pengetahuan IPS. Penelitian yang lain oleh Selvy Wulan Khoirunnisa yang menyimpulkan bahwa ada pengaruh penggunaan model role playing terhadap keterampilan berbicara siswa kelas V SD Negeri 1 Pardasuka. Hal ini ditunjukkan dengan nilai rata-rata keterampilan berbicara siswa yang mengikuti pembelajaran bahasa Indonesia fokus berbicara menggunakan model role playing pada kelas eksperimen (VA) yaitu 78,69 lebih tinggi dari nilai rata-rata keterampilan berbicara siswa yang mengikuti metode pembelajaran ceramah pada kelas kontrol (VB) yang hanya mendapat nilai 63,92.

Kajian penelitian tersebut adalah sama-sama melakukan penelitian eksperimen dan meneliti tentang model pembelajaran role playing. Perbedaannya adalah penelitian ini mencari keterampilan membaca, sedangkan pada penelitian ini mencari data kompetensi pengetahuan IPS. Dari uraian tersebut dapat disimpulkan bahwa model pembelajaran role playing berpengaruh terhadap keterampilan membaca, hal tersebut dikarenakan model pembelajaran role playing dapat membuat siswa lebih aktif dan suasana kelas akan menjad menyenangkan, sehingga nanti model pembelajaran role playing juga akan berpengaruh pada kompetensi pengetahuan IPS.

\section{Simpulan dan Saran}

Berdasarkan hasil penelitian dan uraian pembahasan, adapun yang dapat disimpulkan yaitu (1) kompetensi pengetahuan IPS pada kelompok eksperimen yang dibelajarkan dengan model pembelajaran role playing berbasis tat twam asi diperoleh rata-rata gain skor, $\overline{\mathrm{X}}=0,60$. Rata-rata gain skor kompetensi pengetahuan IPS tersebut kemudian dikonversikan pada tabel skala penilaian atau kategori/klasifikasi pada skala lima teoretik, sehingga dapat diketahui kompetensi pengetahuan IPS siswa kelompok eksperimen pada predikat sangat baik, (2) kompetensi pengetahuan IPS pada kelompok kontrol yang dibelajarkan melalui pembelajaran konvensional diperoleh skor rata-rata gain skor, $X=0,41$. Rata-rata gain skor kompetensi pengetahuan IPS tersebut kemudian dikonversikan pada tabel skala penilaian atau kategori/klasifikasi pada skala lima teoretik,sehingga dapat diketahui kompetensi pengetahuan IPS siswa kelompok kontrol pada predikat sangat baik. (3) terdapat perbedaan yang signifikan kompetensi pengetahuan IPS antara kelompok siswa yang dibelajarkan melalui model pembelajaran role playing berbasis tat twam asi dengan yang dibelajarkan melalui Pembelajaran Konvensional siswa kelas V SD Negeri Gugus Budi Utomo Tahun Ajaran 2016/2017. Hasil analisis data diperoleh thitung Sebesar 4,634. Dengan menggunakan taraf signifikansi $5 \%$ dan $\mathrm{dk}=67$ diperoleh batas penolakan hipotesis nol sebesar 2,00. Berarti thitung > ttabel yaitu 4,634 > 2,00, maka Ho yang diajukan ditolak dan menerima Ha. Pembelajaran dengan menggunakan model pembelajaran role playing berbasis tat twam asi memberikan 
hasil yang lebih baik dibandingkan dengan model pembelajaran konvensional. Adapun saran yang disampaikan kepada sebagai berikut. (1) kepada siswa, disarankan agar memanfaatkan kesempatan yang difasilitasi guru dengan berpartisipasi aktif dalam kegiatan pembelajaran menggunakan model pembelajaran role playing berbasis tat twam asi, sehingga dapat membangun pengetahuan sendiri. Kepada Guru Berdasarkan temuan penelitian yang diperoleh, disarankan kepada guru agar lebih kreatif untuk memberikan fasilitas berupa sumber belajar dan kesempatan yang lebih besar bagi siswa pada pembelajaran dengan menggunakan model pembelajaran role playing berbasis tat twam asi sehingga tercipta pembelajaran bermakna bagi siswa, (2) Kepada Kepala Sekolah disarankan agar dapat menggunakan hasil penelitian ini sebagai pendukung sumber belajar guru dalam meningkatkan kualitas pembelajaran dengan menciptakan pembelajaran yang menggembirakan di sekolah sehingga sekolah mampu menghasilkan siswa yang memiliki output berkualitas, (3) kepada peneliti lain disarankan agar hasil penelitian ini digunakan sebagai referensi untuk melaksanakan penelitian selanjutnya atau menemukan inovasi kegiatan pembelajaran lainnya yang bermakna bagi siswa.

\section{Daftar Rujukan}

Agung, A. A. Gede. 2006. Evaluasi Pendidikan. Singaraja: IKIP.

Agung, A. A Gede. 2014. Buku Ajar Metodelogi Penelitian Pendidikan. Singaraja: Undiksha.

Arikunto, Suharsimi. 2013. Dasar-Dasar Evaluasi Pendidikan Ed. 2. Jakarta: PT Bumi Aksara

Dantes,Nyoman. 2012. Metode Penelitian. Yogyakarta:ANDI.

Emzir. 2014. Metodelogi Penelitian Pendidikan Kuantitatif \& Kualitatif. Jakarta: PT Rajawali Grafindo Persada.

Gunawan, Rudy. 2011. Pendidikan IPS (Filosofi, Konsep dan Aplikasi). Bandung: Alfa Beta.

Hamalik, Oemar. 2011. Proses Belajar Mengajar. Jakarta: PT Bumi Aksara

Huda, Miftahul. 2014. Model-Model Pengajaran dan Pembelajaran. Yogyakarta: Pustaka Pelajar.

Komara, Endang. 2014. Belajar dan Pembelajaran Interaktif. Bandung: PT Refika Aditama

Kurniasih,Imas dan Berlin Sani. 2016. Ragam Pengembangan Model Pembelajaran Untuk Meningkatkan Profesionalitas Guru. Jakarta: Kata Pena.

Kosasih. 2014. Strategi Belajar dan Pembelajaran (Implementasi Kurikulum 2013). Bandung: Yrama Widya.

Koyan, I Wayan. 2012. Statistik Pendidikan. Singaraja : Undiksha

Kunandar. 2014. Penilaian Autentik (Penilaian Hasil Belajar Peserta Didik Berdasarkan Kurukulum 2013). Jakarta: PT Raja Grafindo Persada.

Ngalimun. 2016. Strategi dan Model Pembelajaran. Banjarmasin: Aswaja Presindo.

Setyosari, Punaji. 2015. Metode Penelitian Pendidikan \& Pengembangan. Jakarta: Perdanamedia Group.

Susanto, Ahmad. 2015. Teori Belajar \& Pembelajaran di Sekolah Dasar. Jakarta: Perdanamedia Group.

Sugiyono. 2009. Metode Penelitian Pendidikan (Pendekatan Kuantitatif, Kualitatif, dan R\&D). Bandung: CV. Alvabeta.

Sugiyono. 2013. Statistika untuk Penelitian. Bandung: Alfabeta.

Sugiyono. 2016. Metode Penelitian Kuantitatif, Kualitatif, dan R\&D. Bandung: Alfabeta.

Suhardana, Komang. 2010. Tat Twam Asi Ajaran Kesamaan Martabat Manusia. Surabaya: Paramita.

Sukardi. 2012. Metodelogi Penelitian Pendidikan (Kompetensi dan Praktiknya).Yogyakarta: PT Bumi Aksara. 